\title{
(A Conceptual Framework for Understanding Customer aßC Satisfaction in Banking Sector: The Mediating Influence of Service Quality and Organizational Oath
}

\author{
Amitav Saha*, K.M Sabbir Hasan, Md. Salah Uddin
}

Assistant Professor, Department of Management Studies, University of Rajshahi, Rajshahi, BANGLADESH

*E-mail for correspondence: amitav_asaub@yahoo.com

Received: Aug 14, 2014;

Accepted: Aug 27, 2014;

Published: Sep 11, 2014

Source of Support: Nil

No Conflict of Interest: Declared

\begin{abstract}
With the economic intensification of a country is on accelerating mode, role of banking industry is also important in this growth. In a hyper-competitive market all commercial banks in Bangladesh are faced with challenges of retaining the existing and attracting new customers. The aim of the research is to take the opinions of different peoples in Rajshahi city, Bangladesh about the service quality in different commercial banks. Samples of 51 customers who have their bank account with different commercial banks having operations in Rajshahi city are selected on convenience basis. This paper presents an original survey in the banking sector of Rajshahi City, Bangladesh. To achieve the main goal of the research, the authors of the paper developed questionnaire designed for bank clients. After going for long analysis we have found that five factors playing important role in order to make customer happy regarding the banking services. Therefore, customer satisfaction is the key for many banks to stay alive in competition.
\end{abstract}

Keywords: Customer Satisfaction, Service Quality, Customer Centrism, Customer Relationship Management

JEL Code: M1, M0, M31

\section{INTRODUCTION}

Expansion of the banking system influences and accelerates the economic growth and development of Bangladesh. The Bangladeshi banking industry has shown enormous growth during the past one to two decades. Commercial banking is a service industry and it delivers services to the consumer. And, it is strongly believed that a satisfied customer is the best person to generate positive word of mouth for a commercial bank.

Modern banking business is comprehensively influenced by the process of globalization. The impact is expressed, mainly, in financial market liberalization that, in turn, causes an augmented competition. To survive in a competitive struggle, banks should offer their customers something new and relatively cheap, because the competitive power of a bank is largely defined by the degree of its conformance to customer needs. In the information age, organizations need new capabilities for competitive success, such as customer relationships, product innovation, customized products, employee skills, motivation, and information technology (Titko et.el , 2010). The banking industry in Bangladesh has undergone sea change post independence. More recently, liberalization, the opening up of the economy in the 1990s and the government's decision to privatize banks by reduction in state ownership culminated in the banking reforms. This has led the Bangladeshi banking industry to experience difficult times. In such testing times of mature and acute competitive pressures, it is very urgent and important that banks are able to retain a loyal base of clients. To attain this and to improve their market and profit positions, banks in have to formulate their strategies and policies towards increasing customer satisfaction levels. (Mistry, 2013)

Banking institutions across the globe have acknowledged the significance of customer satisfaction and of developing and maintaining long-lasting relationship with their customers as two essential parameters leading to increased business profits. At the same time, several banking institutions are experiencing rising level of retail customer displeasure. Research suggests that customer dissatisfaction is still the major reason of bank customers' switch to other banks (Manrai and Manrai, 2007). This dissatisfaction could be because of a variety of reasons.

Excellent service quality is not an elective spirited strategy which may, or may not, be adopted to separate one bank from another: today it is necessary to corporate profitability and survival. The link between service quality and customer satisfaction has been submitted to 
concentrated scrutiny by leading service quality researchers (Bitner and Hubbert, 1994)

In a hyper-competitive market all commercial banks in Bangladesh are faced with challenges of retaining the existing and attracting new customers. The maintaining bank's existing customer base is even more important than the ability to capture new clients. One of the reasons is that the cost of attracting a new customer is much higher than the cost of keeping existing one. Thus, customer satisfaction and loyalty are essential to bank's success. Customer loyalty is a major contribution to sustainable profit growth.

\section{SigNIFICANCE OF THE STUdY}

Convalescing service quality has being the most important goal of service industries for the past three decades, most especially when studies have linked customer satisfaction with good service quality. This is true, on the whole, in commercial banking where there is petite or no segregation of the products offered. The alternative means of retainingexpanding the customer base is to enlarge the quality of services provided to uphold customer satisfaction. Sustaining customer satisfaction is very crucial to banks incessant existence since no bank can linger in business without loyal customers. Researchers have enumerated the benefits of customer loyalty as a result of their satisfaction in the quality of services obtained from their service providers. These include augmented profit, decrease in service cost, better perceptive of financial affairs and needs of their clients and the chance to cross-sell the old and new products. Some other benefits are positive words of mouth, inclination to pay charged price and proclivity to see one's bank as a "relationship" bank.

\section{LITERATURE REVIEW}

Customer satisfaction has been considered the essence of success in today's highly competitive banking industry. Different researchers have found the factors which might affect customer satisfaction with respect to commercial banking in the world.

Kumar (2013) in his research paper found that a customer gives highest impotence to reliability dimension. Within that reliability dimension they give more focus on how banks fulfil their promise and how they show interest to do work. From Analysis it was found that a customer gives second importance to responsiveness of bank employees. It includes various criteria like, promptness in giving service, willingness to help customers etc. Customer gives third preference to assurance factor, it include criteria like safety of transaction, consistency in service etc. Abdullah, et al (2011) tested the relationship among the three dimensions of service quality and customer satisfaction in New Zealand. All the three factors, reliability, assurance and enabling are significant predictors of customer satisfaction in retail banking in New Zealand. Therefore, any policy to improve customer satisfaction in retail banking in New Zealand will know what to target and according to what priority, either from the government or the managers of these industries. Arbore and Busacca (2009) conducted an broad study on the determinants of customer satisfaction in retail banks by obtaining data from a well-known retail bank in Italy. Using a survey data from 5000 customers, and a revised methodology that deviate from the traditional approach, they were able to confirm non-linear and asymmetry relationship among the characteristics of performances and customers" overall satisfaction. In essence, their finding shows disparity between the results obtained using the tradition and revised methodology. Prabhakaran and Satya (2003) mentioned that the customer is the king. Heskett et al. (1997) argued that profit and growth are stimulated primarily by customer loyalty. Ndubisi (2005), Gee et al. (2008) and Pfeifer (2005) pointed out that the cost of serving a loyal customer is five or six times less than a new customer. Several researchers including Tariq and Moussaoui (2009), Han et al. (2008) and Ehigie (2006) found that loyalty is a direct outcome of customer satisfaction. Generally speaking, if the customers are satisfied with the provided goods or services, the probability that they use the services again increases (East, 1997). Also, satisfied customers will most probably talk enthusiastically about their buying or the use of a particular service; this will lead to positive advertising (File and Prince, 1992; Richens, 1983). On the other hand, dissatisfied customers will most probably switch to a different brand; this will lead to negative advertising (Nasserzadeh et al., 2008). The significance of satisfying and keeping a customer in establishing strategies for a market and customer oriented organization cannot be ignored (Kohli and Jaworski, 1990).Levesque and McDougall (1996) studied the determinants of customer satisfaction in retail bank in Canada. Data was obtained from a survey of 325 church goers. They used 17 items to measure service quality and service features on a 7-point Likert scale, ranging from 1, strongly disagree to 7 , strongly agree.

Considering the above literature it is evident that there are very few studies conducted in banking sector relating to the influence of service quality and organisational oath for understanding customer satisfaction. Majority of the previous research point towards that customer satisfaction can be found by qualitative analysis using critical incidents, focus groups and depth interviews, thus in this regard researcher assume that item generation barely through literature review or responses throughout structured questionnaire would not be adequate. And, furthermore none of the previous studies performed to determine the factors leading to customer satisfaction in commercial banking speciality in Rajshahi city and this indicates a research gap in the existing literature regarding the determination of factors for customer satisfaction in Bangladeshi Banking sector. The phenomenon of customer satisfaction in commercial banks, and finding the factors for customer satisfaction in Rajshahi city in particular, has not yet been studied with the application of extensive quantitative analysis. This indicates a research gap in the existing literature regarding the influence of service quality 
and organisational oath for understanding customer satisfaction in commercial banking sectors in Bangladesh. This leads us to the major objective of the study.

\section{Objectives of the Study}

The aim of the research is to take the opinions of different peoples in Rajshahi city about the service quality in different commercial banks. Therefore, the specific objectives of this paper are:

- To get an insight into the quantitative parameters of customer satisfaction

- To analyze the results obtained from the authors' conducted survey among different commercial bank's in Rajshahi city, and

- To know the various important service quality dimension in banking industry

- To know the satisfaction level of customers of bank in each service dimension

\section{ReseARCH Methodology}

For the data collection, sample of 51 customers who have their bank account with different commercial banks having operations in Rajshahi city on convenience basis. As the study is about measuring service quality of commercial banks, the population included mainly clients of different private banks like- Brac Bank, Dutch-Bangla bank, Eastern Bank, Mercantile Bank, Dhaka Bank and The Standard Bank, which are located in the Rajshahi city .Next, the questionnaire was given to the customers for evaluating their answer pertaining to different dimensions of service quality in banks. . After data collection, by using SPSS software (17.0 versions), different statistical analysis have been conducted to test the strength of associations between the study variables Based on literature review, items were recognized to assess the satisfaction level of bank customers. For identifying the satisfaction factors, the respondents were asked to rate their bank on various categories. All the items were put on a five-point likert scale ranging from strongly disagree to strongly agree. We conducted exploratory factor analysis (EFA) on the data composed to make sure that the items loaded well on their designated constructs with a very high reliability. The EFA is conceded factor by factor since we are utilizing a uniform dimensional scale in other to remove poorly loaded indicator(s) from each of the constructs before carrying out the reliability test and to be sure the items on each construct are measuring the same thing (Hair et al., 2010). The initial questionnaire items for the latent variables of the customer satisfaction in the model consisted of 15 manifest indicators from which 10 are eventually removed. The remaining five indicators are adopted and used for this study. We employed principal component analysis (PCA) of the factor extraction technique, using veri-max rotation option to obtain factors of maximum variance with Eigen value of 1 and above from a data set with few orthogonal components. This is appropriate for variable reduction prior to performing CFA. All the items have factor loadings of more than 0.7 on their construct.

\section{Descriptive Statistical Analysis}

This section revolves around analyzing the selected sample's demographic characteristics. The following statistics were noticed from the analysis:

Table 1: Output of frequency analysis of the gender variable Gender

\begin{tabular}{|l|l|c|c|c|c|}
\hline \multirow{2}{*}{ Valid } & Fale & 40 & 78.4 & 78.4 & 78.4 \\
\cline { 2 - 6 } & Female & 11 & 21.6 & 21.6 & 100.0 \\
\cline { 2 - 6 } & Total & 51 & 100.0 & 100.0 & \\
\hline
\end{tabular}

From table $1,78.4 \%$ of the sample responses were received by males as opposed to the $21.6 \%$ from females.

Table 2: Output of frequency analysis of the educated variable Education Level

\begin{tabular}{|c|c|c|c|c|c|}
\hline \multirow{2}{*}{ Valid } & Frequency & Percent & $\begin{array}{c}\text { Valid } \\
\text { Percent }\end{array}$ & $\begin{array}{c}\text { Cumulative } \\
\text { Percent }\end{array}$ \\
\cline { 2 - 6 } & Master's & 45 & 88.2 & 88.2 & 100.0 \\
\cline { 2 - 6 } & Total & 51 & 100.0 & 100.0 & \\
\hline
\end{tabular}

Table 2, it is apparently reflects that the sample customers within Rajshahi city held 45\% master's degree, 6\% Bachelor degree. It also helps the importance of the academic and professional development of the Banks.

Table 3: Output of frequency analysis of the age of respondents

\begin{tabular}{|c|c|c|c|c|c|}
\hline \multicolumn{1}{|c|}{} & Frequency & Percent & $\begin{array}{c}\text { Valid } \\
\text { Percent }\end{array}$ & $\begin{array}{c}\text { Cumulative } \\
\text { Percent }\end{array}$ \\
\hline Valid & $20-30$ & 6 & 11.8 & 11.8 & 11.8 \\
\cline { 2 - 6 } & $30-40$ & 38 & 74.5 & 74.5 & 86.3 \\
\cline { 2 - 6 } & $40-50$ & 7 & 13.7 & 13.7 & 100.0 \\
\cline { 2 - 6 } & Total & 51 & 100.0 & 100.0 & \\
\hline
\end{tabular}

With regards to the age, it is evident that most of the responses received were from customers between the age 3040 years, with the percentage of $06 \%$ between the age 20-30, in comparison to the $07 \%$ of those age is more than 40 years.

Table 4: Output of frequency analysis of the years of experience variable

\begin{tabular}{|c|c|c|c|c|c|}
\multicolumn{7}{c|}{ Service Length } \\
\hline \multirow{4}{*}{ Valid } & Frequency & Percent & $\begin{array}{c}\text { Valid } \\
\text { Percent }\end{array}$ & $\begin{array}{c}\text { Cumulative } \\
\text { Percent }\end{array}$ \\
\cline { 3 - 7 } & 2-5 years & 14 & 27.5 & 27.5 & 27.5 \\
\cline { 2 - 7 } & 10 years & 33 & 64.7 & 64.7 & 92.2 \\
\cline { 2 - 7 } & Total & 51 & 100.0 & 100.0 & 100.0 \\
\hline
\end{tabular}

From the table 4, with regards to the years of experience category, it is evident that most of the responses received were from customers involved in service sector in Rajshahi 
City that have experience more than 5 years or more, with the percentage of $64.7 .5 \%$, in comparison to the $27.5 \%$ of those working for less than 5 years; $7.8 \%$ for those working for more than 10 years. According to the above percentages, one would conclude (assume) that majority of the sample respondent have got 5-10 years working experience.

Table 5: Output of frequency analysis of the Marital Status Marital Status

\begin{tabular}{|c|c|c|c|c|c|}
\hline \multirow{2}{*}{ Valid } & Married & 48 & 94.1 & 94.1 & 94.1 \\
\cline { 2 - 6 } & Single & 3 & 5.9 & 5.9 & 100.0 \\
\cline { 2 - 6 } & Total & 51 & 100.0 & 100.0 & \\
\hline
\end{tabular}

From Table 5, it is observed that With regard to marital status, $94.1 \%$ is married and $5.9 \%$ respondents are single.

Table 6: Output of frequency analysis of the Salary

\begin{tabular}{|c|c|c|c|c|c|}
\hline & & Frequency & Percent & $\begin{array}{c}\text { Valid } \\
\text { Percent }\end{array}$ & $\begin{array}{c}\text { Cumulative } \\
\text { Percent }\end{array}$ \\
\hline Valid & $\begin{array}{c}\text { Below } \\
\text { Tk 15000 }\end{array}$ & 5 & 9.8 & 9.8 & 9.8 \\
\cline { 2 - 6 } & $\begin{array}{c}\text { Below } \\
\text { Tk 30,000 }\end{array}$ & 25 & 49.0 & 49.0 & 58.8 \\
\cline { 2 - 6 } & $\begin{array}{c}\text { Over } \\
40000\end{array}$ & 21 & 41.2 & 41.2 & 100.0 \\
\hline & Total & 51 & 100.0 & 100.0 & \\
\hline
\end{tabular}

From the table 6, with regards to the salary, it is evident that most of the responses received were from employees that have salary level below $15000 \mathrm{Tk}, 21 \%$ respondent are between salary level over $40000 \mathrm{Tk}$, and only $25 \%$ respondents belongs salary less than 30,000Tk.

\section{INFERENTIAL STATISTICAL ANALYSIS}

\section{Table 7: Output of KMO and Bartlett's Test} KMO and Bartlett's Test

This table shows the results of Kaiser-Meyer-Olkin $(\mathrm{KMO})$ and Bartlett's test of factors based on the information collected on selected variables. High values (between 0.50 to 1.0) indicate that factor analysis is appropriate. Values below 0.50 imply that factor analysis may not be appropriate. KMO measures the Sphericity of sampling adequacy as an index used to examine the appropriateness of factor analysis. In this case, KMO reveals the sampling adequacy indicating (value of $0.50<$ $\mathrm{KMO}<1.0$ ) i.e. 0.676 for selected customer's using banks facilities in Rajshahi city is appropriate for the same. Bartlett's Test of Sphericity is a test of statistic used to test the hypothesis that the variables are uncorrelated in the population. The population correlation matrix is an identity Matrix, each variable correlates perfectly with

\begin{tabular}{|c|c|c|}
\hline \multicolumn{2}{|c|}{$\begin{array}{r}\text { Kaiser-Meyer-Olkin Measure } \\
\text { of Sampling Adequacy }\end{array}$} & .676 \\
\hline \multirow{2}{*}{$\begin{array}{c}\text { Bartlett's Test } \\
\text { of Sphericity }\end{array}$} & Approx. Chi-Square & 390.924 \\
\cline { 2 - 3 } & Df & 105 \\
\cline { 2 - 3 } & Sig. & .000 \\
\hline
\end{tabular}

itself(r=1) but no correlation with the other variables $(\mathrm{r}=0)$. Bartlett's Test of Sphericity indicates that approximate chi-square value is 390.924 with 105 (df) for .000 levels of significance. Hence, the factor analysis is considers as an appropriate technique.

Table 8: Output of Communalities Extraction Method: Principal Component Analysis

\section{Communalities}

\begin{tabular}{|l|c|c|}
\hline & Initial & Extraction \\
\hline Bank safety and guarantees & 1.000 & .896 \\
\hline $\begin{array}{l}\text { Emotional aspect of service (kindliness and } \\
\text { courtesy of bank staff) }\end{array}$ & 1.000 & .891 \\
\hline Service costs & 1.000 & .796 \\
\hline Qualification of bank employees & 1.000 & .649 \\
\hline $\begin{array}{l}\text { Level of ATM's network development; Use of } \\
\text { innovations; Usability of bank products }\end{array}$ & 1.000 & .626 \\
\hline Service speed & 1.000 & .688 \\
\hline The level of branch network development & 1.000 & .768 \\
\hline Spent waiting time in queue & 1.000 & .700 \\
\hline $\begin{array}{l}\text { Bank opening hours; Request fulfilment time; } \\
\text { Bank reputation }\end{array}$ & 1.000 & .659 \\
\hline Simplicity of information acquisition & 1.000 & .715 \\
\hline Variety of bank offered products and services & 1.000 & .809 \\
\hline $\begin{array}{l}\text { Branch environment (technical facilities, interior } \\
\text { decoration etc.) }\end{array}$ & 1.000 & .879 \\
\hline $\begin{array}{l}\text { Professional appearance of front office } \\
\text { employees }\end{array}$ & 1.000 & .773 \\
\hline Bank participation in social projects & 1.000 & .678 \\
\hline Quality of bank & 1.000 & .767 \\
\hline
\end{tabular}

The above output is a table of communalities which shows how much of the variance in the variables has been accounted for by the extracted factors. For instance over $89 \%$ of the variance in safety and guarantees in Banks is accounted for while $79.0 \%$ of the variance in service cost is accounted for. The next item shows all the factors extractable from the analysis along with their Eigen values, the percent of variance attributable to each factor, and the cumulative variance of the factor and the previous factors. It is observed that the first factor accounts for $25.922 \%$ of the variance, the second $21.328 \%$ and the third $11.378 \%$. Excepting the first 5 components all the remaining factors are not significant.

Table 9: Output of Total Variance Explained Extraction Method: Principal Component Analysis

\section{Total Variance Explained}

\begin{tabular}{|l|l|l|l|l|l|l|}
\hline \multirow{2}{*}{ Component } & \multicolumn{3}{|c|}{ Initial Eigenvalues } & \multicolumn{3}{c|}{$\begin{array}{c}\text { Extraction Sums } \\
\text { of Squared Loadings }\end{array}$} \\
\cline { 2 - 7 } & Total & $\begin{array}{c}\% \text { of } \\
\text { Variance }\end{array}$ & $\begin{array}{c}\text { Cumula } \\
\text { tive \% }\end{array}$ & Total & $\begin{array}{c}\text { \% of } \\
\text { Variance }\end{array}$ & $\begin{array}{c}\text { Cumula } \\
\text { tive \% }\end{array}$ \\
\hline 1 & 3.888 & 25.922 & 25.922 & 3.888 & 25.922 & 25.922 \\
\hline 2 & 3.199 & 21.328 & 47.249 & 3.199 & 21.328 & 47.249 \\
\hline 3 & 1.708 & 11.387 & 58.637 & 1.708 & 11.387 & 58.637 \\
\hline 4 & 1.451 & 9.670 & 68.307 & 1.451 & 9.670 & 68.307 \\
\hline 5 & 1.049 & 6.995 & 75.302 & 1.049 & 6.995 & 75.302 \\
\hline 6 & .975 & 6.502 & 81.805 & & & \\
\hline
\end{tabular}




\begin{tabular}{|l|l|l|l|l|l|l|}
\hline 7 & .624 & 4.158 & 85.963 & & & \\
\hline 8 & .518 & 3.455 & 89.417 & & & \\
\hline 9 & .390 & 2.599 & 92.017 & & & \\
\hline 10 & .338 & 2.256 & 94.272 & & & \\
\hline 11 & .288 & 1.921 & 96.193 & & & \\
\hline 12 & .232 & 1.547 & 97.740 & & & \\
\hline 13 & .141 & .942 & 98.682 & & & \\
\hline 14 & .123 & .821 & 99.503 & & & \\
\hline 15 & .075 & .497 & 100.000 & & & \\
\hline
\end{tabular}

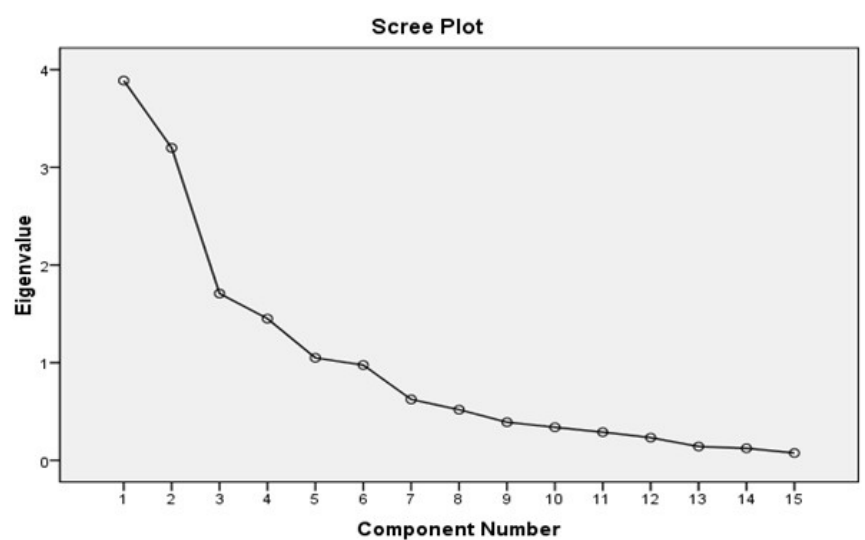

The Scree plot is a graph of the Eigen values against all the factors. The graph is useful for determining how many factors to retain. The point of interest is where the curve starts to flatten. It can be seen that the curve begins to flatten between factors 5 and 6 . Note also that factor 5 has an Eigen value of more than 1 , so only five factors have been retained. The next table below shows the loadings of the eight variables on the five factors extracted. The higher the absolute value of the loading, the more the factor contributes to the variable. The gap on the table represent loadings that are less than 0.5 , this makes reading the table easier. We suppressed all loadings less than 0.5 .

Table 10: Output of Total Component Matrix of selected variables Extraction Method: Principal Component Analysis Component Matrix

\begin{tabular}{|l|c|c|c|c|c|}
\hline & \multicolumn{5}{|c|}{ Component } \\
\hline & 1 & 2 & 3 & 4 & 5 \\
\hline Bank safety, guarantees & .877 & -.061 & -.293 & .186 & -.058 \\
\hline $\begin{array}{l}\text { Emotional aspect of service } \\
\text { (kindliness and courtesy of bank } \\
\text { staff) }\end{array}$ & .855 & -.168 & -.309 & .181 & .055 \\
\hline Service costs & .530 & -.115 & .231 & .308 & .595 \\
\hline Qualification of bank employees & .599 & -.017 & -.339 & -.416 & -.029 \\
\hline $\begin{array}{l}\text { Level of ATM's network } \\
\text { development; Use of innovations; } \\
\text { Usability of bank products }\end{array}$ & -.080 & -.555 & .235 & .471 & -.187 \\
\hline Service speed & .428 & .265 & .639 & .151 & -.051 \\
\hline $\begin{array}{l}\text { The level of branch network } \\
\text { development }\end{array}$ & .534 & .302 & .322 & -.421 & -.333 \\
\hline Spent waiting time in queue & .710 & -.136 & .171 & -.182 & -.340 \\
\hline
\end{tabular}

\begin{tabular}{|l|c|c|c|c|c|}
\hline $\begin{array}{l}\text { Bank opening hours; Request } \\
\text { fulfilment time; Bank reputation }\end{array}$ & .065 & .327 & .686 & .064 & .271 \\
\hline $\begin{array}{l}\text { Simplicity of information } \\
\text { acquisition }\end{array}$ & .012 & .640 & .201 & .306 & -.414 \\
\hline $\begin{array}{l}\text { Variety of bank offered products } \\
\text { and services }\end{array}$ & .168 & .860 & -.073 & .179 & -.067 \\
\hline $\begin{array}{l}\text { Branch environment (technical } \\
\text { facilities, interior decoration etc.) }\end{array}$ & -.036 & .899 & -.229 & -.045 & .127 \\
\hline $\begin{array}{l}\text { Professional appearance of front } \\
\text { office employees }\end{array}$ & -.067 & .772 & -.340 & .135 & .195 \\
\hline $\begin{array}{l}\text { Bank participation in social } \\
\text { projects }\end{array}$ & .243 & .036 & .264 & -.659 & .338 \\
\hline Quality of bank & .819 & -.065 & -.093 & .275 & .082 \\
\hline
\end{tabular}

a. 5 components extracted

From the above analysis five important factors deciding customer satisfaction in banking sector in Rajshahi Division are extracted. These are:

1. Bank safety, guarantees

2. Branch environment (technical facilities, interior decoration etc.)

3. Bank opening hours; Request fulfilment time; Bank reputation

4. Service speed

5. Service costs

Table 11: Output of Descriptive Statistics of components extracted Descriptive Statistics

\begin{tabular}{|l|l|l|l|}
\hline & Mean & Std. Deviation & $\mathrm{N}$ \\
\hline Quality of bank products & 3.70 & .463 & 50 \\
\hline Bank safety, guarantees & 3.6600 & .47852 & 50 \\
\hline Service costs & 2.7200 & .49652 & 50 \\
\hline Service speed & 2.5600 & .54060 & 50 \\
\hline $\begin{array}{l}\text { Bank opening hours; Request } \\
\text { fulfilment time; Bank reputation }\end{array}$ & 3.1000 & .41650 & 50 \\
\hline $\begin{array}{l}\text { Branch environment (technical } \\
\text { facilities, interior decoration etc. })\end{array}$ & 3.4000 & .49487 & 50 \\
\hline
\end{tabular}

Table 12: Model summery of predictors and dependent variables Model Summary (b)

\begin{tabular}{|l|l|l|l|l|l|}
\hline Model & R & $\begin{array}{l}\text { R } \\
\text { Square }\end{array}$ & $\begin{array}{l}\text { Adjusted } \\
\text { R Square }\end{array}$ & $\begin{array}{l}\text { Std. Error of } \\
\text { the Estimate }\end{array}$ & $\begin{array}{l}\text { Durbin- } \\
\text { Watson }\end{array}$ \\
\hline 1 & $.846 a$ & .716 & .684 & .260 & 2.172 \\
\hline
\end{tabular}

a. Predictors: (Constant), Branch environment (technical facilities, interior decoration etc.), Bank safety, guarantees, Bank opening hours; Request fulfilment time; Bank reputation, Service speed, Service costs

b. Dependent Variable: Quality of bank products

The five selected influencing variables collectively explain i.e., $R=84.6$ percent of variations in customer's satisfaction. The Adjusted R squire is .684 percent. The coefficient of determination is 0.846; therefore, about $84.60 \%$ of the variation in the satisfaction data is explained by the selected variables. The regression equation appears to be very useful for making predictions since the value of $\mathrm{r} 2$ is close to 1 . 
Table 13: Model summery of analysis variance $\operatorname{ANOVA}(\mathbf{b})$

\begin{tabular}{|c|c|c|c|c|c|c|}
\hline \multicolumn{2}{|c|}{ Model } & $\begin{array}{l}\text { Sum of } \\
\text { Squares }\end{array}$ & Df & $\begin{array}{l}\text { Mean } \\
\text { Square }\end{array}$ & $F$ & Sig. \\
\hline \multirow[t]{3}{*}{1} & Regression & 7.520 & 5 & 1.504 & 22.212 & $.000 \mathrm{a}$ \\
\hline & Residual & 2.980 & 44 & .068 & & \\
\hline & Total & 10.500 & 49 & & & \\
\hline
\end{tabular}

a. Predictors: (Constant), Branch environment (technical facilities, interior decoration etc.), Bank safety, guarantees, Bank opening hours; Request fulfillment time; Bank reputation, Service speed, Service costs

b. Dependent Variable: Quality of bank products

What we do see here from the above table is the F-test outcome that we mentioned earlier as giving a measure of the absolute fit of the model to the data. Here, the F-test outcome is highly significant, so the model does fit the data. A straight line, depicting a linear relationship, described the relationship between these selected variables.

Table 14: Model summery of Unstandardized and Standardized Coefficients Dependent Variable: Quality of bank products

\section{Coefficients (a)}

\begin{tabular}{|l|l|c|c|c|c|c|}
\hline \multirow{2}{*}{ Model } & \multicolumn{2}{|l|}{$\begin{array}{l}\text { Unstandardized } \\
\text { Coefficients }\end{array}$} & $\begin{array}{l}\text { Standardized } \\
\text { Coefficients }\end{array}$ & & \\
\cline { 2 - 6 } & $\mathrm{B}$ & Std. Error & Beta & $\mathrm{t}$ & Sig. \\
\hline 1 & .398 & .490 & & .812 & .421 \\
\hline (Constant) & .768 & .088 & .794 & 8.746 & .000 \\
\hline Bank safety, guarantees & .074 & .087 & .080 & .857 & .396 \\
\hline Service costs & .052 & .079 & .060 & .657 & .515 \\
\hline Service speed & .139 & .102 & .125 & 1.361 & .180 \\
\hline $\begin{array}{l}\text { Bank opening hours; } \\
\text { Request fulfilment time; } \\
\text { Bank reputation }\end{array}$ & & & & & \\
\hline $\begin{array}{l}\text { Branch environment } \\
\text { (technical facilities, } \\
\text { interior decoration etc.) }\end{array}$ & -.081 & .077 & -.087 & 1.053 & .298 \\
\hline
\end{tabular}

As we know that, the beta value is a measure of how strongly each predictor variable influences the criterion variable. And, the beta is measured in units of standard deviation. In this case, Bank safety, guarantees has got highest beta value (.794) that means a change of one standard deviation in case of Bank safety; guarantees will result in a change of .794 standard deviations in the satisfaction level of customers of commercial banks in Rajshahi city. Thus the higher the beta value the greater the impact of the predictor variable on the criterion variable.

Table 15: Model summery of Residuals Statistics Residuals Statistics (a)

\begin{tabular}{|l|c|c|c|c|c|}
\hline & Minimum & Maximum & Mean & $\begin{array}{c}\text { Std. } \\
\text { Deviation }\end{array}$ & $\mathrm{N}$ \\
\hline Predicted Value & 2.91 & 4.10 & 3.70 & .392 & 50 \\
\hline Residual & -.897 & .819 & .000 & .247 & 50 \\
\hline Std. Predicted Value & -2.020 & 1.014 & .000 & 1.000 & 50 \\
\hline Std. Residual & -3.449 & 3.148 & .000 & .948 & 50 \\
\hline
\end{tabular}

a. Dependent Variable: Quality of bank products

\section{Normal P-P Plot of Regression Standardized Residual}

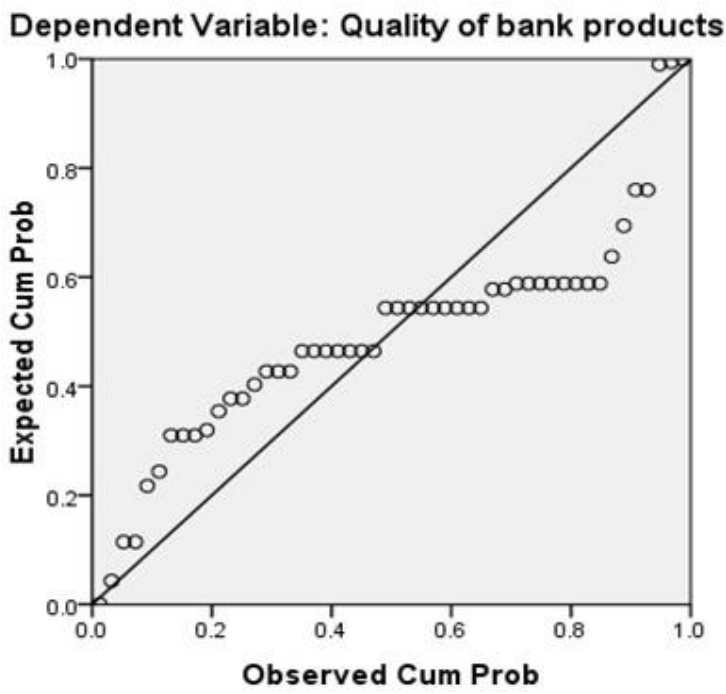

Table 11: Output of correlation matrix extracted components

\section{Correlations}

\begin{tabular}{|c|c|c|c|c|c|c|c|}
\hline & & $\begin{array}{l}\text { Quality of } \\
\text { bank } \\
\text { products }\end{array}$ & $\begin{array}{l}\text { Service } \\
\text { costs }\end{array}$ & $\begin{array}{l}\text { Bank safety, } \\
\text { guarantees }\end{array}$ & $\begin{array}{c}\text { Bank opening hours; } \\
\text { Request fulfilment time; } \\
\text { Bank reputation }\end{array}$ & $\begin{array}{c}\text { Service } \\
\text { speed }\end{array}$ & $\begin{array}{l}\text { Branch environment } \\
\text { (technical facilities, } \\
\text { interior decoration etc.) }\end{array}$ \\
\hline \multirow[t]{3}{*}{ Quality of bank products } & Pearson Correlation & 1 & $.426^{* *}$ & $.820^{* *}$ & .053 & .277 & -.089 \\
\hline & Sig. (2-tailed) & & .002 & .000 & .715 & .051 & .538 \\
\hline & $\mathrm{N}$ & 50 & 50 & 50 & 50 & 50 & 50 \\
\hline \multirow[t]{3}{*}{ Service costs } & Pearson Correlation & $.426^{* *}$ & 1 & $.364^{* *}$ & .237 & $.292^{*}$ & -.116 \\
\hline & Sig. (2-tailed) & .002 & & .009 & .098 & .040 & .421 \\
\hline & $\mathrm{N}$ & 50 & 50 & 50 & 50 & 50 & 50 \\
\hline \multirow[t]{3}{*}{ Bank safety, guarantees } & Pearson Correlation & $.820^{* *}$ & $.364^{* *}$ & 1 & -.133 & .199 & -.017 \\
\hline & Sig. (2-tailed) & .000 & .009 & & .357 & .166 & .905 \\
\hline & $\mathrm{N}$ & 50 & 50 & 50 & 50 & 50 & 50 \\
\hline \multirow{3}{*}{$\begin{array}{l}\text { Bank opening hours; } \\
\text { Request fulfilment time; } \\
\text { Bank reputation }\end{array}$} & Pearson Correlation & .053 & .237 & -.133 & 1 & $.381^{* *}$ & .099 \\
\hline & Sig. (2-tailed) & .715 & .098 & .357 & & .006 & .494 \\
\hline & $\mathrm{N}$ & 50 & 50 & 50 & 50 & 50 & 50 \\
\hline
\end{tabular}




\begin{tabular}{|c|c|c|c|c|c|c|c|}
\hline \multirow[t]{3}{*}{ Service speed } & Pearson Correlation & .277 & $.292^{*}$ & .199 & $.381^{* *}$ & 1 & .137 \\
\hline & Sig. (2-tailed) & .051 & .040. & .166 & .006 & & .342 \\
\hline & $\mathrm{N}$ & 50 & 50 & 50 & 50 & 50 & 50 \\
\hline \multirow{3}{*}{$\begin{array}{l}\text { Branch environment } \\
\text { (technical facilities, } \\
\text { interior decoration etc.) }\end{array}$} & Pearson Correlation & -.089 & -.116 & -.017 & .099 & .137 & 1 \\
\hline & Sig. (2-tailed) & .538 & .421 & .905 & .494 & .342 & \\
\hline & $\mathrm{N}$ & 50 & 50 & 50 & 50 & 50 & 50 \\
\hline
\end{tabular}

**. Correlation is significant at the 0.01 level (2-tailed)

*. Correlation is significant at the 0.05 level (2-tailed)

The results of this study demonstrates all service quality dimensions are positively correlated with customer satisfaction indicating quality banking service as a prerequisite for having a satisfied customers. According to the correlation result, Bank safety and guarantees are the dominant determinants of customer satisfaction. This point out that commercial banks should compulsory initialize condition of caring, individualized concentration given to the customers. Moreover, administrator should persuade service recovery and problem solving attitude prevailing in their banks.

The positive significant coefficient for customer satisfaction and Service costs relationship suggests higher customers have significant concern over the increasing service cost in private commercial banks. Therefore organizations should always strive to ensure that their customers are very satisfied regarding different service cost. Moreover, Bank opening hours, request fulfilment time and Bank reputation is potentially one of the most powerful weapons that financial institutions to gain a strategic advantage and survive in today's ever-increasing competitive environment. Moreover, banks need to develop strategies that enhance loyalty of their customers.

\section{POLICY IMPLICATIONS AND SUGGESTION}

This study has a number of repercussions for the commercial banks in Rajshahi city. It has not only acknowledged the proportions of service quality that include customer satisfaction, but also how significant each of these indicators is to their dimensions according to the customers "insight". Therefore, any policy to advance customer satisfaction in Commercial banking in Bangladesh will know what to target and according to what priority, either from the government or the managers of these industries. However, it should be noted that more studies need to be done to authenticate this findings, in particular with a larger sample size. Further studies that will assess this finding across the demographic variables and bank ownership are also recommended for the good of commercial banks in Bangladesh. Thus researcher recommend following issues:

- The staff should be effectively trained and skilled to deal with the customer on one to one basis.

- Banks need to perk up their infrastructure to have speed with the challenging environment.

- Many of the services desires upgrading e.g., ATM amenities.

- Staff should be effectively skilled to persuade face to face dealing.
- Staff should be friendly and amicable.

- Clearly defined customer policy should be espoused by the banks

- Customer's needs have to be anticipated in advance so that they can be helped out in a better way.

- Treat your customers like your acquaintances and they'll always come back.

\section{CONCLUSION}

The main objective of this work is to get an insight into the quantitative parameters of customer satisfaction by assessing the service quality dimensions that determine customer satisfaction in selected commercial banks in Rajshahi city. We have selected 15 influencing variables initially. After going for long analysis we have found that five factors playing important role in order to make customer happy regarding the banking services. From the findings, all the indicators used to measure the constructs are all statistically significant based on the survey responses. Thus, we conclude that the indicators are good measure of the constructs.

Basically, this study has done three things. The first was the profiling of the socio-economic characteristics of the respondents, using descriptive statistics. Our findings show that males are the majority of the respondents; they are of average age of between 30-40 years, highly educated with various types of occupations. Most of them $(64.7 \%)$ have more than 5 years experience with their profession.

The second achievement of this study is the establishment of measurement model for customer satisfaction in commercial banks. All the items included in the measurement scale with the exception of one were good measures of their corresponding constructs.

Finally, the study tested the relationship among the five dimensions of satisfaction and banks quality. All the five factors, Service costs, Bank safety, guarantees, Bank opening hours; Request fulfilment time; Bank reputation, Service speed, Branch environment (technical facilities, interior decoration etc.) are significant predictors of customer satisfaction in commercial banking in Rajshahi city. However, the finding of this study should be taken with caution and more studies are needed to validate the finding especially with large samples.

In this paper we have found that a customer gives highest impotence to Bank safety, guarantees dimension. Within that reliability dimension they give more focus on how banks fulfil their promise and how they show interest to do work. From Analysis it was found that a customer gives second 
importance to Service costs. It includes various criteria annual service charge, inter-banking transaction fees, tax provision in deposits etc. Customer gives third preference Service speed, it include criteria like transaction procession time, on time service facilities, prompt responses from front desk services, online transaction speed, etc.

\section{LIMITATIONS OF THE STUDY AND FURTHER RESEARCH}

It is strongly believed that the more diverse the profiles of the respondents more will be the insights into the construct of customer satisfaction for the Bangladeshi banking sector. If the profiles of the respondents were more diverse, the researcher might have received more insights into customer satisfaction for Bangladeshi commercial banking sector from the interviews and the focus groups. The researchers might have generated more factors leading to customer satisfaction. Researchers might undertake similar approach in future to understand customer satisfaction in commercial banking under different situational contexts viz. customer satisfaction in the case of service failure and also post-service recuperation customer satisfaction. This will allow the banks to handle the delivery of their different services better.

\section{REFERENCES}

Abdullah, Asri, et.al (2014) “Determinants of Customer Satisfaction on Retail Banks in New Zealand: An Empirical Analysis Using Structural Equation Modelling", Global Economy and Finance Journal Vol. 7. No. 1. March 2014. Pp. 63 - 82

Abebe, E. (2014). The effect of service quality and core banking on customer satisfaction in commercial bank of Ethiopia. American Journal Of Trade And Policy, 1(2), Full Thesis. Retrieved from http://journals.abc.us.org/index.php/ajtp/article/view/Abebe

Ahmed A, and Dey MM. 2009. Bank loan officers' perceptions of corporate financial disclosure in the banking sector of Bangladesh: An empirical analysis. Proceedings of the 2nd COMSATS International Business Research Conference, Lahore, Pakistan.

Ahmed AA and Ahmad M. 2009. An Empirical Analysis of Performance Measurement of the Disclosure in Financial Reporting: A Study of Banking Sector in Bangladesh. COMSATS Institute if Information Technology 2nd COMSATS International Business Research Conference. Lahore, Pakistan: CIIT.

Ahmed, A., \& Siddique, M. (2013). Internet Banking Espousal in Bangladesh: A Probing Study. Engineering International, 1(2), 40-47.

Retrieved

from http://journals.abc.us.org/index.php/ei/article/view $/ 2.4 \% 281 \% 29$

Akhter, M. (2014). Service Gap of Selected Public and Private Commercial Banks in Bangladesh. Global Disclosure Of Economics And Business, 1(2), 18-30. Retrieved from http://ischolar.in/index.php/GDEABC/article/view/54516

Alam, N., \& Rubel, A. (2014). Impacts of Corporate Social Responsibility on Customer Satisfaction in Telecom Industry of Bangladesh. ABC Journal Of Advanced Research, 3(2), 26-37. Retrieved from http://journals.abc.us.org/index.php/abcjar/article/view/6.3

Angur, M.G., Nataraajan, R. and Jahera, J.S. (1999), "Service quality in the banking industry: an assessment in a developing economy", International Journal of Bank Marketing, Vol. 17 No. 3, pp. 116-23.

Arbore, A and Busacca, B 2009, "Customer satisfaction and dissatisfaction in retail banking: exploring the asymmetric impact of attribute performance, "Journal of Retailing and Consumer Services", Vol.16, pp. 271-280.

Armstrong, R.W. and Seng, T.B. (2000), “Corporate-customer satisfaction in the banking industry of Singapore", International Journal of Bank Marketing, Vol. 18 No. 3, pp. 97-111.

Bedi, M. (2010), “An integrated framework for service quality, customer satisfaction and behavioural responses in Indian banking industry: a comparison of public and private sector banks", Journal of Services Research, Vol. 10 No. 1, pp. 157-72.

Carman, J.M. (1990), “Consumer perceptions of service quality: an assessment of the SERVQUAL dimensions", Journal of Retailing, Vol. 66, pp. 33-5.

Chouwdhury, K. (2008), "Service quality: insights from the Indian banking scenario", Australasian Marketing Journal, Vol. 16 No. 1, pp. 48-61.

Cui, C.C., Lewis, B.R. and Park, W. (2003), "Service quality measurement in the banking sector in South Korea", International Journal of Bank Marketing, Vol. 21 No. 4, pp. 191- 201.

Gee, R., Coates, G. and Nicholson, M. (2008), “Understanding and profitably managing customer loyalty", Marketing Intelligence \& Planning, Vol. 26 No. 4, pp. 359-74.

Gounaris, S.P., Stathakopoulos, V. and Athanassopoulos, A.D. (2003), "Antecedents to perceived service quality: an exploratory study in the banking industry", The International Journal of Bank Marketing, Vol. 21 Nos 4/5, pp. 168-90.

Hossain, M., Abdullah, A., \& Farhana, S. (2012). Performance Appraisal \& Promotion Practices on Private Commercial Bank in Bangladesh: A Case Study from Pubali Bank Ltd. Asian Business Review, 1(1), 49-55. Retrieved from http://i-scholar.in/index.php/ABRABC/article/view/54407

Jamal, A. and Naser, K. (2002), “Customer satisfaction and retail banking: an assessment of some of the key antecedents of customer satisfaction in retail banking", International Journal of Bank Marketing, Vol. 20 No. 4, pp. 146-60.

Jamal, A. and Naser, K. (2003), “Factors influencing customer satisfaction in the retail banking sector in Pakistan", International Journal of Commerce \& Management, Vol. 13 No. 2, p. 29.

Jham, V. and Mohd, K. (2009), "Customer satisfaction and its impact on performance in banks: a proposed model", South Asian Journal of Management, Vol. 16 No. 2, pp. 109- 26.

Kumar, M., Kee, F.T. and Charles, V. (2010), "Comparative evaluation of critical factors in delivering service quality of banks: an application of dominance analysis in modified SERVQUAL model", International Journal of Quality \& Reliability Management, Vol. 27 No. 3, pp. 351-77.

Kumar, M., Kee, F.T. and Manshor, A.T. (2009), "Determining the relative importance of critical factors in delivering service quality of banks: an application of dominance analysis in SERVQUAL model", Managing Service Quality, Vol. 19 No. 2, pp. 211-28.

Ladhari, R. (2008), “Alternative measure of service quality: a review", Journal of Managing Service Quality, Vol. 18 No. 1, pp. 65-86.

Lassar, W.M., Manolis, C. and Winsor, R.D. (2000), "Service quality perspectives and satisfaction in private banking", The Journal of Services Marketing, Vol. 14 No. 3, pp. 244-71.

Lovelock, C. (2001), "Loyalty in private retail banking: an empirical study", IUP Journal of Management Research, Vol. 9 No. 4, pp. 21-38. 
Manrai, L.A. and Manrai, A.K. (2007), "A field study of customers' switching behaviour for bank services", Journal of Retailing and Consumer Services, Vol. 14, pp. 208-15.

Miah, R. (2013). A Framework on Internet Banking Services for the Rationalized Generations. Asian Business Review, 3(4), 71-77. Retrieved fromhttp://ischolar.in/index.php/ABRABC/article/view/54453

Mihelis G.et.al ,(2011) "(CUSTOMER SATISFACTION MEASUREMENT IN THE PRIVATE BANK SECTOR" Sofokleous 11, 10235 Athens, GREECE

Mishra, A.A. (2009), "A study on customer satisfaction in Indian retail banking", IUP Journal of Management Research, Vol. 8 No. 11, pp. 45-61.

Mistry, Snehalkumar, (2013) "Measuring Customer Satisfaction in Banking Sector: With Special Reference to Banks of Surat City" Asia Pacific Journal of Marketing \& Management vol.2 (7), July (2013), p132. ISSN 2319-2836

Naeem, H. and Saif, I. (2009), "Service quality and its impact on customer satisfaction: an empirical evidence from the Pakistani banking sector", The International Business and Economics Research Journal, Vol. 8 No. 12, p. 99.

Okpara, G.S and Onuoha, O.A (2013) "Bank selection and patronage by University students: A survey of students in
Umudike, Nigeria", Asian Business Review, vol. 2, no 2 (issue 4), pp 12 - 18.

Parasuraman, A., Berry, L.L. and Zeithaml, V.A. (1988), "SERVQUAL: a multiple-item scale for measuring consumer perceptions of service quality", Journal of Retailing, Vol. 64 No. 1, p. 12.

Rahman, H. (2014). Employees Motivation in Public and Private Commercial Banks in Bangladesh: A Study on Need-based Approach. Global Disclosure Of Economics And Business, 2(2), 84-91. Retrieved from http://ischolar.in/index.php/GDEABC/article/view/54543

Rashed Al Karim, 2013 "Customer Satisfaction on Service Quality in Private Commercial Banking Sector in Bangladesh" The Qualitative Report, Volume 18, Article 56, 1-21 http:// www.nova.edu/ssss/QR/QR18/mandal56.pdf

Titko, Jelena (2010) "Customer Satisfaction and Loyalty in Latvian Retail Banking", Journal of Economics and Management", p-15, ISSN 1822-6515

Uddin, Belal (2012)"Determinants of Customer Satisfaction of Banking Industry in Bangladesh" Pak. J. Commer. Soc. Sci. 2012 Vol. 6 (2), 242-256

--0 -- 